Ситосанова Ольга Владимировна, к.филол.н., доцент, Ангарский государственный технический университет, e-mail: violets-f@mail.ru

ЯЗЫКОВАЯ КАРТИНА МИРА

\title{
LANGUAGE PICTURE OF THE WORLD
}

Sitosanova O.V.

Аннотация. Языковая картина мира отражает восприятие мира носителями данной культуры. В статье рассматриваются различия между англоязычной и русскоязычной культурами.

Ключевые слова: языковая картина мира, языковая личность, лексикон, тезаурус, прагматикон.

Abstract. The linguistic picture of the world reflects the perception of the world by the bearers of this culture. The article discusses the differences between English-speaking and Russian-speaking cultures.

Keywords: linguistic picture of the world, linguistic personality, lexicon, thesaurus, pragmaticon.

Картина мира представляет собой определенным образом организованные знания о мире, свойственные когнитивной системе или ее модели $[1, \mathrm{c}$. 146]. С одной стороны, в картину мира входят общие знания о мире, которые можно считать «объективными». С другой стороны, в картине мира присутствуют и знания другого типа, которые условно можно назвать «субъективные». Это - ценности, обобщающие опыт индивида и социума.

Языковая картина мира объективно отражает восприятие мира носителями данной культуры. Но человеческое отражение не является механическим, оно носит творческий (и поэтому субъективный) характер. Оно предполагает не только воздействие на субъект извне, но и активное действие самого субъекта, его творческую активность, которая проявляется в избирательности и целенаправленности восприятия, в отвлечении от одних предметов, свойств и отношений и фиксировании других, в оперировании чувственного образа в логическую мысль, в оперировании понятиями.

Различия между англоязычной и русскоязычной культурами, в общем и целом, носят неслучайный характер. Они обусловлены комплексом причин, которые могут быть сгруппированы в три класса: исторические, географические и психологические.

Так, по мнению Дж. Горера, основу английского национального характера составляют такие качества, как неприятие внешнего контроля, свободолюбие, незначительный интерес к сфере интимных отношений по сравнению с соседними народами, предупредительность, агрессивность [6].

Согласно И.М. Кобозевой, «основу русского национального характера составляют такие качества, как щедрость, неорганизованность, но в тоже время человек, «верящий в победу добра и правды и не стесняющий себя во всем 
остальном» [5]. Для русской ментальности идея непостижимости событий является очень важной. Применительно к эмоциональности лингвист говорит о неконтролируемости эмоций в русском языке и категоричности их выражения [3].

Человеческое общение является одной из форм социального взаимодействия. Выступая в роли языковой личности, человек выполняет одну из своих социальных функций. Данная роль подразумевает наличие следующих знаний и целей, с которыми языковая личность вступает в общение:

1) лексикон - сумма знаний человека о естественном языке, включающая знания словарного состава и грамматики;

2) тезаурус - сумма понятий, идей и представлений, которые человек приобретает относительно окружающего мира в ходе своего развития;

3) прагматикон - система целей, мотивов, интересов и психологических установок человека, которыми он руководствуется в своей жизнедеятельности, включая и речевую деятельность [4].

Поскольку процесс человеческой деятельности подразумевает наличие правил и конвенций, с помощью которых можно регулировать эту деятельность, то и речевая деятельность также протекает в соответствии с определенными правилами. По мнению В.В. Богданова, «владение этими правилами речевого общения образует знания о межличностных взаимодействиях и умение их применять в процессе коммуникации» [2].

Таким образом, социальные нормы поведения являются необходимым условием существования общества. Они регулируют социальное взаимодействие людей в процессе их практической деятельности. Жизнь любого общества невозможна без соблюдения социальных норм, являющихся своего рода регуляторами речевого поведения коммуникантов в ряде типичных коммуникативных ситуаций.

\section{ЛИТЕРАТУРА}

1. Баранов А.Н. Лингвистическая теория аргументации (Когнитивный подход): дис. ... д-ра фрил. наук: 10.02.01, 10.02.19. / А.Н. Баранов. - М.: АН ИРЯ, 1990. - 372 с.

2. Богданов В.В. Коммуникативная компетенция и коммуникативное лидерство / В.В. Богданов. - Тверь: ТГУ, 1990. - С. 26-31.

3. Вежбицкая А. Язык. Культура. Познание / А. Вежбицкая. - М.: Русские словари, 1996. - 416 с.

4. Караулов Ю.Н. Русский язык и языковая личность / Ю.Н. Караулов. М.: Наука, 1987. - 262 с.

5. Кобозева И.М. Лингвистическая семантика / И.М. Кобозева. - М.: Эдиториал УРСС. - 2000. - 352 с.

6. Gorer J. Exploring English Character / J Gorer. - New York: Criterion Books, 1955. -328 p. 